REPRINTS FROM THE "BRITISH MEDICAL JOURNAL."

THE Scotsman of July 9th publishes the following: "Messrs. Smith Elder, and Co. have published the first two numbers of a series of One contains a paper on "Compulsory Vaccination," written by Mr. Ene contains a paper on "Compulsory Vaccination," written by Mr. pulsory Notification in England and Wales in 1892," the other on "State pulsory Notification in England and Wales in 1892," the other on "State contributions to the literature of public health, and their publication in this separate form

ERratum.

DR. T. LAUDER BRUNTON (Stratford Place, W.) writes: I shall be obliged if you will kindly allow me to correct an error in the report of $\mathrm{my}$ speech, on page 15 of the last number of the BRITISH MEDICAL JOURNAL. The experiments on chloroform in 18

\section{The Griffiths FUND.}

Drs. E. Le Cronier Lancaster (Winchester House, Swansea), and W. F. BROoK (Northampton Terrace, Swansea), Hon. Secretaries, desire to
acknowledge the following additional subscriptions to the above fund :

\begin{tabular}{|c|c|c|c|}
\hline wledged & & & \\
\hline . 11. Jont & & $\ldots$ & \\
\hline Howell Rees, Glan Garnant ... & ... & $\cdots$ & \\
\hline $\begin{array}{l}\dot{V} \text {. Davis, Llandilo ... } \\
\text {.... }\end{array}$ & $\ldots$ & $\ldots$ & \\
\hline
\end{tabular}

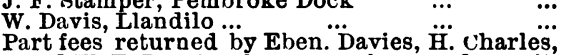
and W. F. Brook, who were subpœnaed as witnesses at the trial

\section{Legitimate and Illegitimate SPEcialism.}

SPECIALISM in medicine and in treatment is necessary in many departments where the growth of modern knowledge has been rapid. The legitimate specialist is one who, having a special mental bent and special advantages for making a iparticular class of observations, uses them not only for his own advantage but also for he knows, so that a general knowledge, of the subject may be advanced, and treatment of a certain class of patients improved thereby. On the other hand, a bad form of specialism is the assumption of knowledge and of a position of precedence with an amount of self-advertisement which is objectionable in any professional vosition. These remarks apply equally to medicine and to any profession dealing with the treatment of patient by any methods. We regret to see that a prospectus has been issued bearing the name of a teacher in one of our great educational colleges advertising that special advice and recomraendation as to consultation of medical specialists is offered in connection with defects of speech. We trust blished educational body.

Rival "CURES."

IT is amusing to read how the proprietors of rival "cures" love one another. In a recent prospectus of one of the multitude of "cures" for inebriety we read that in one period of two years this "latest triumph of medical science" was successfully used in the treatment of 1,019 cases, 92 of swhich had been absolute failures, of the " gold cure treatment." Further, it is asserted that the treatment from the start restores to health and builds up the wasted and dis-
eased nerve centres instead of prostrating the system, as is
the case with bichloride of gold." Need we add that the proprietor claims that his "discovery" "has been absolutely successful"?

\section{The LATE MR DAVID TAYLOR.}

DR. A. J. WALL (Paris) writes: In your obituary notice of Mr. David Taylor there is an omission that I feel sure is not intentional on your part. You only mention three of Mr. Taylor's sons. Fourteen year's ago, as many of your readers will remember, there was a landslip occasioning much loss of life at Naini Tal, in the North-West Provinces of India. A portion of the hiliside fell, burying some of the inhabitants under it. The civil officer in charge of the district at once organised a party to endeavour to rescue those engulfed, he himself superintending the operation. Whilst engaged in this perilous task a greater landslip occurred, burying him and all those with him. This officer was Mr. Leonard Taylor, of the Indian Civil Service, assistant magistrate of the district, and those who knew him will bear witness to the bright promise of the young life he thus sacrificed at the call of duty. He was a son of Mr. David Taylor, and a brother of forget deeds like these.

\section{Doctors in Parliament.}

THE medical profession is much better represented in the Frencl Chambers than in our own House of Commons. and the medical legislators take measures to make their Parliamentary influence felt when the occasion arises. What might be called an "extra-Parliamentary Medical Committee" has recently been constituted. The medica members of the two legislative Chambers assembled at the Palais Bourbon on June 21st for this purpose, and decided to form a "group" for the examination of the numerous questions which concern the medical profession, the organisation of medical aid for the sick poor and the protection of the public health. M. Berthelot, Senator, was lected President of the "group;" MM. L. Labbé, Senator, Cornil, Senator, and Lannelongue, Deputy, Vire-Presidents; MM. Dellestable, Senator", and Pedebidou, Deputy, Secretaries; M. Guéneau. Deputy, Quastor-Treasurer. In addition to these the group comprises the following Senators M.M. Combes (Charente Inférieure), Clautemps (Seine), Clédon and Quintan (Basses Pyrenées), Le Borgne (Finistère), Coilat (Haut saône),
Demoulins de Riols (Landes), Francoz (Haute Savoie), Frézoul (A' iége),
Gérente (Algiers), Ouvrier (Aveyron), Rolland (Tarn-et Garonne), and Tanlier (Vaucluse); and the following members of the Chamber of (Charente Inférieure), Bourgoin (Ardennes), Bourrillon (Lozère), (Allier), Delbet (Seine-et-Marne), Gueneau (Cote d Or), Guignard (Allier), Delbet (Seine-et-Marne), Gueneau (Côte d Or), Guignard
(Maine-et-Loire), Guillemant (Sione-et Loire), Isaac (Guadeloupe), Legludic (Sarthe), Leroy (Somme), De Mahy (ia Réunion), Marfan (Aude), Pourteyron (Dordogne), and Ricard (Côte-d'Or').

\section{LETTERS, COMMUNICATIONS, ETC, have been received from :}

(A) An Old Member; Dr. T. M. Allison, Guisborough. (B) Mr. F. Bass, London; Mr. W Bernard, Londonderry ; Dr. H. T. Bulstrode, London; Dr. C Y. Biss, London; Messrs. Baiss Brothers and Co., London; Dr. T. Lauder Brunton, London; Mr. W. F. Brook, Swansea; Mr. W. Boyle, London ; Mr. T. Blair, Leeds; T P. Beddoes, M.B., Aberystwsth; Dr. F. R. Blaxall, Lendon; G. M. Brown, M.B., Tunstall. (C) Mr. S. Craddock, Bath; Mr. J. Coombs, Bridgwater; Dr. M. Copeman, London ; Dr. J. M. Clarke, Clifton; Mr. J. D. Costine, Iiverpool; Mr. J. Cleavers, London; Mr. H. Calvert, London. (D) Dr. T. M. Dolan, Halifax; Mr. J. Dacre, Clifton; Dr. C. Dukes, Rugby ; Mr. W. Dalton, Blackpool; Mr. H. Davis, London. (ㅍ) Mr. G. M. Edwards London; Ealing Surgeon; G. Eastes, M.B., London; Mr. E. A. B. Elliot, Kingsbridge. (F) Mr. L. Fletcher, Ipswich ; Mr. M. B. Foster, Leicester ; Dr. R. Farrar, Stamford ; Mr. C. E. S. Flemming, Freshford. (G) Mr. A. Gray, Birmingham; Dr. A. L. Gillespie, Edinburgh Mr. G. A. Gibson, Edinburgh ; Dr. J. Gairdner, Crieff. (H) Mr. H. W. Hayes, London; Mr. A. Hawkes, Launceston: G. Halley, M.B., Broughty Ferry; Hants. (I) Dr. C. R. Illingworth, London; Infanticide. (J) Mr. V. C. Jones, Presteign ; Justitia. (K) Kidderminster Medical Society, Secretary of, Kidderminster; Dr. R. Kirk, Glasgow. (I) Mr. S. R. Lister, Lynn; Mr. H. Littlewood, Leeds; Mr. N. B. Langley, Cricklade; Mr. A. Lavery, Manchester ; Mr. E. Little, London; R. Lyddon, M.B., Deal; Dr. W. G. V. Lush, Weymouth (M) Mr. W. L. Mackenzie, Newton Stewart; Mr. T. Murtagh, West Brighton; Mr. G. B. Mead, Newmarket; Mr. G. R. Murray, Newcastle; Mr. S. W. Macllwaine, South Petherton; Mr. J. Mackie, Not tingham ; M.B.A. ; Marza Manufacturing Company, London. (N) Mr. P. Newell, Crowborough: Mr. J. J. Newitt, Leeds. (P) Mr. J. Paynter, London; Mr. J. O. Pemberton, Birmingham; Phthisis; Professor J. Penbertlyy, London; Dr. C. E. Purslow, Birmingham; Parochial. (R) Royal Microscopical Society of London, Secretary of, London; Royal Society, Secretary of, London; Mr. R. Rae, London Dr. J. Robertson, Dumbarton; Dr. J. M. Rhodes, Didsbury; Mr. A. Reid, London; Mr. R. G. Roberts, Penmaenmawr; Dr. E. Rice Oxford. (S) Messrs. F. Stearns and Co., London; Mr. J. Stewart Clifton; Mr. R. R. Sleman, London; Mr. F. J. Smith, London Straddles; Dr. E. M. Sympson, Lincoln; Dr. J. T. Sutherland, London C. E. A. Semple, M.B., London; Mr. T. Smith, London; Dr. J. Smyth, London; G. F. Still, M.B., London. (T) Miss L. Twining, Tunbridge Wells; Mr. R. S. Thomas, London : A. Taylor, M.B., Bolton ; Dr. J. C. Taylor, Windermere; A. Tuthill, M.B., Parkstone. (U) Union Medical Officer. (W) Mr. W. J. II. Wood, Boston; Dr. A. J. Wall, Paris ; Mr. C. A. Whitney, Liverpool ; Mr. R. C. Worsley, Ramsgate Mr. J. T. Walters, Nottingham; Dr. L. A. Weatherley, Bath; Mr. H White, Manchester; E. E. Waters, M.B., Sheffield; Mr. F. Windsor, Manchester; J. H. Wilks, M.B, Sheffield; Mr. A. Wiglesworth, Liverpool. (Y) Mr. N. E. Yorke-Davies, London; etc.

\section{BOOKS, ETc., RECEIVED.}

The Pharmacopnia of the Hospital for Diseases of the Throat (Golden Square). Edited by F. G. Harvey. 5th Edition. London: J. and A. Churchill. 1894. 2s. 6d

Organic Chemistry. Part I. By W. H. Perkin, jun, and F. S. Kipping. London and Edinburgh: iv. and R. Chamhers. 1894.

A Compend of General Pathology and Morbid Anatomy. By Dr. H. N. Hall. London and Edinburgh: Young J. Pentland. 1891

The Retrospect of Medicine. Edited by Dr. J. Braithwaite Vol. CIX, January to June, 1894. London: Simpkin, Marshall, Hamilton, Kent and Co.

Edinburgh Hospital Reports. Edited by Dr. G. A. Gibson, Dr. C. W. Catlcart, Dr. J. Thomson, and Dr. D. B.

Handbuch der praktischen Gewerbehygiene. Herdusgegeben von Dr H. Albrecht. Lieferung I. Berlin: Gustav Schmidt. 1894. M 4.50.

Clinical Diagrams, with Dirertions for Recording Cases of Hearts Disease. By Dr. G. Herschell. London: Bailliere, Tindall and Cox.

Diagrams for Recoriing Cases of IIeart Disease. By Dr. G. Ilerschell. London: Baillicre, Tindall and Cox. 1894. 6d.

Income Tax: How to Get it Refunded. Bv A. Chapman. 10th Edition. London: Effinghan, Wi'son and Co. 1394.9.j. 1s. 6d.

*** In forwarding bocks the pub'ishers are requested to state the selïing prices. 